University of Michigan Law School University of Michigan Law School Scholarship Repository

\title{
Class Gifts under the Restatement (Third) of Property
}

Lawrence W. Waggoner

University of Michigan Law School, waggoner@umich.edu

Available at: https://repository.law.umich.edu/articles/387

Follow this and additional works at: https://repository.law.umich.edu/articles

Part of the Estates and Trusts Commons

\section{Recommended Citation}

Waggoner, Lawrence W. "Class Gifts under the Restatement (Third) of Property." Ohio N. U. L. Rev. 33, no. 3 (2007): 993-1012.

This Article is brought to you for free and open access by the Faculty Scholarship at University of Michigan Law School Scholarship Repository. It has been accepted for inclusion in Articles by an authorized administrator of University of Michigan Law School Scholarship Repository. For more information, please contact mlaw.repository@umich.edu. 


\title{
Class Gifts under the Restatement (Third) of Property
}

\author{
LAWRENCE W. WAGGONER*
}

The new Restatement (Third) of Property (officially the Restatement (Third) of Property: Wills and Other Donative Transfers), in tandem with the Restatement (Third) of Trusts, is systematically proceeding through the whole field of wills, will substitutes, trusts, and estates. Both of the new Restatements should prove to be handy resources for trust and estate lawyers, not only in preparing to argue cases at both trial and appellate levels, but also in the everyday work of drafting and construing dispositive provisions in wills, trusts, and other types of donative documents. Each Restatement section is followed by a set of Comments explaining and illustrating the black letter and by Reporter's Notes collecting relevant cases, statutes, and secondary sources.

The division of coverage between the Restatement of Property and the Restatement of Trusts is governed more by the history of the American Law Institute (the ALI or Institute) than by logic. The Trusts Restatement is primarily concerned with the validity and administration of trusts, including fiduciary duties of trustees. The Property Restatement is primarily concerned with the validity of gifts, wills, and will substitutes, but also with the construction of the dispositive provisions in trusts as well as those in wills and will substitutes. Consequently, in construing the meaning of a dispositive provision in a trust, the relevant Restatement is the Restatement of Property, not the Restatement of Trusts.

The first two volumes of the Restatement (Third) of Property have now been approved by the ALI and published in hard-bound volumes. Volume 1, published in 1999, covers intestacy, execution and revocation of wills, and post-execution events affecting the meaning of wills, such as ademption, lapse, and antilapse statutes. Volume 2, published in 2003, covers gifts, will substitutes, capacity, undue influence, the elective share of the surviving spouse, ${ }^{1}$ construction, ${ }^{2}$

* Reporter, RESTATEMENT (THIRD) OF PROP.: WILlS AND OTHER DONATIVE TRANSFERS; Lewis M. Simes Professor of Law, University of Michigan.

1. Regarding the elective share of the surviving spouse (also called the forced share or the nonbarrable share), the new Restatement takes the position that revocable trusts are subject to the elective share even if the elective-share statute speaks only of the decedent's probate estate. See RESTATEMENT (THIRD) OF PROP.: WILLS AND OTHER DONATIVE TRANSFERS $\$ 9.1$ (2003). The Restatement's position was adopted in Sieh v. Sieh, 713 N.W.2d 194 (Iowa 2006).

2. The new Restatement takes the position that extrinsic evidence may be considered in resolving an ambiguity, even when the ambiguity is patent rather than latent. See RESTATEMENT (THIRD) OF PROP.: WILLS AND OTHER DONATIVE TRANSFERS $\$ 11.1$ (2003). The Restatement's position was adopted in University of Southern Indiana v. Baker, 843 N.E.2d 528 (Ind. 2006) (rejecting the ancient distinction between latent and patent ambiguities). 
reformation, ${ }^{3}$ and modification of wills ${ }^{4}$ and other donative documents. ${ }^{5}$

Volume 3 , which is scheduled to be published in 2007, will cover class gifts and powers of appointment. Although the material on class gifts, the subject of this brief survey, is not yet published in a hard-bound volume, it is published in soft-cover as Tentative Draft No. 4 (2004), and has been approved in principle by the ALI at the 2004 annual meeting. The class-gift material is available from the $\mathrm{ALI}^{6}$ and is also accessible online from Westlaw and Lexis.

A parallel project is currently working its way through the processes of the Uniform Law Commission (ULC) for amending the Uniform Probate Code (UPC). That project is not as comprehensive as the class gift material in the new Restatement, but does overlap the rules of construction on questions of status of adopted children, nonmarital children, and children of assisted reproduction. ${ }^{7}$ The drafting committee has now approved measures that are largely consistent with the Restatement. Following ULC procedures, the current draft will be given a first reading at the 2007 annual meeting and, after further review and refinement, a final reading and approval at the 2008 annual meeting. To the extent that the UPC amendments, as finally approved, turn out to be in accord with the Restatement, the two will reinforce each other and strengthen the credibility of both.

3. For centuries, courts have ruled that wills cannot be reformed, no matter how convincing the evidence is that the terms were the product of mistake. See John H. Langbein \& Lawrence W. Waggoner, Reformation of Wills on the Ground of Mistake: Change of Direction in American Law?, 130 U. PA. L. REV. 521 (1982). The new Restatement reverses the ancient anti-reformation rule. See RESTATEMENT (THIRD) OF PROP.: WILLS AND OTHER DONATIVE TRANSFERS $\$ 12.1$ (2003). The Restatement's position is that a will can be reformed on a showing of mistake by clear and convincing evidence. The Restatement's position is now adopted in section 415 of the Uniform Trust Code and was applied in In re Herceg, 747 N.Y.S.2d 901 (Sur. Ct. 2002). But see Flannery v. McNamara, 738 N.W.2d 739 (Mass. 2000) (4-2 decision). As one commentator noted about Flannery, "[ $t$ ]he evidence [in favor of reformation] appeared to be quite weak; it could not meet the preponderance standard, let alone the clear and convincing standard." Martin L. Fried, The Disappointed Heir: Going Beyond the Probate Process to Remedy Wrongdoing or Rectify Mistake, 39 REAL PROP. PROB. \& TR. J. 357, 400 (2004).

4. The new Restatement authorizes modification of wills and other donative documents to achieve the donor's tax objectives. See RESTATEMENT (THIRD) OF PROP.: WILLS AND OTHER DONATIVE TRANSFERS $§ 12.2$ (2003) (codified at UNIF. TRUST CODE $\S 416$ ).

5. John Langbein \& Lawrence W. Waggoner, Curing Execution Errors and Mistaken Terms in Wills (unpublished manuscript on how the Restatement (Third) of Property addresses defective execution and drafting errors in wills, on file with author at waggoner@umich.edu).

6. American Law Institute, http://ali.org/ali/propwls.htm (last visted July 1, 2007); American Law Insitute, http://ali.org/ali/onlinepdfs.htm (last visted July 1, 2007). Under the editorial authority granted to the Reporter, as confirmed by the Director of the Institute, the final published volume will deviate somewhat from Tentative Draft No. 4. Two sections- $\$ \S 14.6$ and 14.7-have undergone revisions since the 2004 annual meeting. See infra notes $26,28$.

7. The author serves as Reporter for this drafting committee. Drafts can be downloaded from the Uniform Law Commissioners' website, http://nccusl.org (last visted July 1, 2007). 


\section{General Characteristics Of Class GifTS}

The Restatement material on class gifts (officially Division V) is divided into four chapters-Chapter 13, General Characteristics of Class Gifts; Chapter 14, Presumptive Meaning of Class Gift Terms; Chapter 15, Increase and Decrease in Class Membership; and Chapter 16, Class Gifts to Heirs. Chapter 13, General Characteristics of Class Gifts, begins by defining a class gift and specifying the terms of a disposition that presumptively create a class gift. The chapter also distinguishes a class gift from a disposition to multiple beneficiaries who are intended to take as individuals and not as a class.

A class gift is defined as a disposition to beneficiaries who are described by a group label and are intended to take as a group. ${ }^{8}$ Taking as a group means that the membership of the class is typically not static, but is subject to fluctuation by increase or decrease until the time when a class member is entitled to distribution; and upon distribution, the property is divided among the then-entitled class members on a fractional basis. A disposition to multiple beneficiaries who are intended to take as individuals, and not as a class, means that the disposition is restricted to the identified individuals. ${ }^{9}$ If the terms of the disposition identify the beneficiaries only by a group label (such as "to my children" or "to my issue"), the disposition presumptively creates a class gift. If the terms of the disposition identify the beneficiaries only by name (such as "to A, B, and C"), without any reference to a group label, the disposition does not create a class gift, but is to the named beneficiaries taking as individuals. If the terms of the disposition identify the beneficiaries by a group label and either by name or by the number of beneficiaries who then fit the group label (such as "to my children, A, B, and C" or "to my three children," or "to my three children, A, B, and C"), the disposition is rebuttably presumed not to create a class gift, but is to the beneficiaries taking as individuals.

Important consequences attach to classifying a disposition as a class gift versus a disposition to multiple beneficiaries taking as individuals. A class gift is ordinarily subject to open to allow new members to join the class, but a disposition to individuals is not. A class gift contains within it an implicit gift over of a failed class member's share to the eligible class members, but a disposition to individuals ordinarily does not. Suppose, for example, that a testator's will bequeaths $\$ 100,000$ "to my children" (presumptively a class gift). When the will was executed, the testator had three children-A, B, and

8. See Restatement (ThIRD) OF Prop:: Wills AND OTHER DONATIVE Transfers $\$ 13.1$ (Tentative Draft No. 4, 2004).

9. See id. § 13.2. 
C. After the will was executed, the testator had two more children-D and E. A predeceased the testator but $B, C, D$, and $E$ survived. Because $A$ died without issue, the antilapse statute does not apply. The result is that B,C, D, and $\mathrm{E}$ split the $\$ 100,000$ equally. If, however, the bequest had been "to my three children, A, B, and C" (presumptively a disposition to individuals), D and $E$ would take nothing. ${ }^{10}$ A's one-third would ordinarily not go over to $B$ and $\mathrm{C}$, but would pass to the residuary beneficiary. ${ }^{11} \mathrm{~B}$ and $\mathrm{C}$ would each take their original one-third shares, but no more.

\section{Presumptive Meaning of Class Gift Terms}

Chapter 14, Presumptive Meaning of Class Gift Terms, provides rules of construction that attribute presumptive meaning to terms of relationship that are commonly used as group labels in class gifts, such as "children," "grandchildren," "brothers," "sisters," "nephews," "nieces," "cousins," "issue," and "descendants." A rule of construction controls the meaning of such a term unless the language or circumstances establish that the transferor had a different intention. The burden of proof is on the party who would attribute to the transferor an intent that is different from that attributed by the rule of construction. The importance of careful drafting cannot be overemphasized here because definitions contained in the document override any rule of construction. The role of a rule of construction is to provide meaning when that meaning has not been supplied by the donative document or other evidence of intent. ${ }^{12}$ Note, also, that the scope of the class gift material extends into power of appointment law, for the permissible appointees of a power of appointment and the takers in default of the exercise of a power of appointment are typically described in class gift terms. ${ }^{13}$

The chapter on presumptive meaning of class gift terms begins by distinguishing between single-generation class gifts and multiple-generation class gifts. As their names imply, the takers of a single-generation class gift are restricted to a single generation, ${ }^{14}$ and the takers of a multiple-generation class gift include descendants in the first and more remote generations. ${ }^{15}$

10. D and $\mathrm{E}$ might be awarded a share of the estate under the applicable pretermitted heir statute. See, e.g., UNIF. PROBATE CODE $\S 2-302$ (amended 1993).

11. RESTATEMENT (ThIRD) OF PROP.: WiLls AND OTHER DONATIVE TRANSFERS $\S 13.2 \mathrm{cmts} . \mathrm{d}-\mathrm{g}$ (Tentative Draft No. 4, 2004) (considering factors that tend to rebut the presumption and support implying a gift over despite the form of the disposition).

12. See id. $\$ 11.3$.

13. See, e.g., RESTATEMENT (THIRD) OF PROP.: WILLS AND OTHER DONATIVE TRANSFERS $\$ 19.15$ cmt. d, 19.22 cmt. b,19.23 cmt. a (Tentative Draft No. 5, 2006).

14. See RESTATEMENT (THIRD) OF PROP.: WILLS AND OTHER DONATTVE TRANSFERS Transfers $\S$ 14.1 (Tentative Draft No. 4, 2004).

15. See id. $\$ 14.3$. 
Common single-generation class-gift terms are "children," "grandchildren," "brothers and sisters," and "nieces and nephews." Common multiplegeneration class-gift terms are "issue" and "descendants" (in the Restatement and in the law generally, though not in every jurisdiction, these two terms"issue" and "descendants"-are identical and carry the same meaning). In the case of a single-generation class gift, the property is divided equally among the eligible class members, with no provision for substituting the descendants of deceased class members. ${ }^{16}$ In the case of a multiple-generation class gift, the property is divided "by representation" among the eligible class members. ${ }^{17}$ Because there are various systems of representation, and more than one meaning of the "per stirpes" system, ${ }^{18}$ the importance of carefully defining the system to be used is self-evident. In the absence of a definition in the document, the Restatement adopts the rule of construction that the system of representation to be employed is the one used in the intestacy statute of the domicile of the designated ancestor. ${ }^{19}$

\section{QUESTIONS OF STATUS}

The chapter on presumptive meaning of class-gift terms then turns to questions of status of adopted children, nonmarital children, stepchildren, and children of assisted reproduction. Especially because class gifts are frequently postponed class gifts (either in income or principal), taking effect upon the death of the income beneficiary of a trust, these are questions that will arise increasingly in the future, and can be affected by events (such as births, deaths, and adoptions) occurring decades after the settlor dies. Indeed, with the abolition of the Rule Against Perpetuities and the rise of the perpetual trust, the time interval can be measured not just in decades but in centuries. ${ }^{20}$ Again, the desirability of providing definitive answers to these question in the controlling document cannot be overemphasized. Rules of construction provide presumptive answers to these questions only in default of welldesigned definitions in the controlling document. The rules of construction

16. See id. $\$ 14.2$.

17. See id. $\$ 14.4$.

18. Restatement (THIRD) OF PROP.: Wills AND OTHER DONATIVE TRANSFERS $\S 2.3 \mathrm{cmts}$. c-g (1999) (discussing the different systems of representation and the different meanings attributed to the term "per stirpes"). The Uniform Probate Code section 2-709 contains a useful definition of "per stirpes" that can be adapted to private documents, as well as the definition of the per-capita-at-each-generation system of representation that is adopted in the Uniform Probate Code 2-106 for intestacy. See Raymond H. Young, Meaning of "Issue" and "Descendants," 13 ACPC PROB. NOTES 225 (1988).

19. See RESTATEMENT (THIRD) OF PROP.: WILLS AND OTHER DONATIVE TRANSFERS $\S 14.4 \mathrm{cmt}$. c (Tentative Draft No. 4, 2004).

20. See Lawrence W. Waggoner et al., Family Property law: CaSes and Materials on WILLS, TRUSTS, AND FUTURE INTERESTS ch. 19 (4th ed. 2006). 
provided in the new Restatement are designed to accord with common intention; however, they are adaptable to use in private donative documents.

\section{A. Adopted Children}

In construing a class gift created by the adopting parent, the Restatement's position is that an adopted child is a child of the adopting parent. ${ }^{21}$ In construing a class gift created by someone other than the adopting parent, the Restatement's position is that the adopted child is treated as a child of the adopting parent, but only if: (i) the adoption took place before the child reached the age of majority; or (ii) the adopting parent functioned as a parent of the child ${ }^{22}$ before the child reached the age of majority or was the child's stepparent or foster parent. ${ }^{23}$ The purpose of the rule pertaining to class gifts created by someone other than the adopting parent is to prevent someone other than the transferor from engaging in a manipulative adoption-such as adopting an adult with whom there was no parent-child relationship (a spouse, for example, or a domestic partner ${ }^{24}$ ) to make that person a beneficiary under a class gift created by someone else. The transferor has in effect given the

21. See Restatement (ThiRd) of Prop.: Whls and Other Donative Transfers $\S 14.5$ (Tentative Draft No. 4, 2004).

22. Functioning as a parent of the child "requires conduct substantially consistent with the conduct of a parent, i.e., voluntarily assuming parental responsibilities toward the child. Conduct that would tend to satisfy this requirement includes conduct such as fulfilling parental responsibilities toward the child, recognizing or holding out the child as his or her child, materially participating in the child's upbringing, bringing the child into the adopting parent's household as a regular member of that household, or assuming custody of the child." See id. $\$ 14.5 \mathrm{cmt}$. f. Additional factors are listed in Reporter's Note No. 4 to section 14.5 .

23. See id. § 14.5 .

24. A recent newspaper report described a case in which the daughter of the chief executive of I.B.M. had adopted her same-sex partner. The adopted same-sex partner has now claimed to take as a child of her adopting partner under a trust established by the latter's father. The case has not yet been resolved, and is complicated by the fact that the two partners have broken up, and the adopting partner is now living with her new same-sex partner. See Pam Belluck \& Alison Leigh Cowan, Partner Adopted by an Heiress Stakes Her Claim, N.Y. Times, Mar. 19, 2007.

The case law has been hostile to allowing an adopted spouse or domestic partner to take under a class gift created by someone other than the adopter. See, e.g., In re Belgard's Trust, 829 P.2d 457 (Colo. Ct. App. 1991) (rejecting claim by adopted wife to be included in a class gift to her husband's children in a trust created by the husband's mother); Minary v. Citizens Fidelity Bank \& Trust Co., 419 S.W.2d 340 (Ky. 1967) (holding wife who was adopted by her husband under the state's adoption statute was not treated as a child for purposes of determining the takers of a class gift to heirs found in her mother-in-law's will). In First National Bank of Dubuque v. Mackey, 338 N.W.2d 361 (Iowa 1983), the settlor's daughter adopted her "friend" with whom she "shared an apartment" when she was 58 and the friend was 44 . The daughter's purpose in adopting her friend was to make her friend the sole beneficiary of her mother's trust. The court held that she should not be included as a member of the class named in the mother's trust absent evidence that the adopted adult had an in loco parentis relationship with the adopter. 
donee authority, similar to the authority given an agent, to determine who the donee's "children" or "issue" are. However, the transferor's use of the term "children" or "issue" implies an intent to include only adoptees with whom the adopter had developed an actual parent-child relationship. Note that this rule rejects the old common-law stranger-to-the-adoption doctrine, under which such children are presumptively excluded from class gifts created by someone other than the adopting parent, regardless if the adopting parent had developed an actual parent-child relationship with the adopted child.

A more difficult question is whether an adopted child continues to be treated as a child of the child's genetic parents. Here, the Restatement's position is that an adopted child is not treated for class-gift purposes as a child of either genetic parent, but there are exceptions to the rule. ${ }^{25}$ If the adoption is by the spouse or domestic partner of a genetic parent, the child remains a child of both genetic parents. ${ }^{26}$ If the adoption is by a relative of either genetic parent, or by the spouse or surviving spouse or domestic partner or surviving domestic partner of such a relative, the child also remains a child of both genetic parents. Finally, if the adoption occurs after the death or incapacity of either genetic parent, the child remains a child of both genetic parents if the adoption is by someone nominated by a genetic parent to be the child's guardian. If the adoption is by someone who was not nominated by a genetic parent to be the child's guardian, the child remains a child of a genetic parent from whom or from whose family the child does not subsequently become estranged.

The Restatement commentary gives illustrations of each of these rules and exceptions. For example, the rule that if the adoption is by a relative of either genetic parent, the child remains a child of both genetic parents is illustrated by the following example: Father and Mother, a married couple with one child, $X$, were killed in an airplane crash. After the deaths of Father and Mother, Mother's sister, A, and A's husband, B, adopted X. Unless the facts or circumstances establish that the transferor had a different intention, $\mathrm{X}$ is treated as a child of Father and Mother for class-gift purposes. Thus, for example, if Father's parent (Grandfather) had established a trust to pay the income to his wife, Grandmother, for life, then to pay the principal by representation to Grandfather and Grandmother's descendants who survive Grandmother (the income beneficiary), $X$ would be included as a member of the class. X's adoption by $A$ and $B$ would not remove $X$ from the class.

25. See Restatement (ThIRD) OF PROP.: WiLls AND OTHER DONATIVE Transfers $\$ 14.6$ (Tentative Draft No. 4, 2004).

26. As published in Tentative Draft No. 4, section 14.6 provided that the child only remained a child of the genetic parent whose spouse or domestic partner adopted the child. As this section will appear in the final published volume, the child will remain a child of both genetic parents. See supra note 6. 


\section{B. Nonmarital Children}

Regarding children of parents not married to each other (nonmarital children), the Restatement again draws a distinction between a class gift created by the nonmarital child's genetic parent and a class gift created by someone else. In construing a class gift created by the child's genetic parent, the nonmarital child is presumptively treated as a child of the child's genetic parent. ${ }^{27}$ In construing a class gift created by someone other than the child's genetic parent, a nonmarital child is also treated as a child of the child's genetic parent, but only if: (i) the generic parent, the genetic parent's grandparent or a descendant of the genetic parent's grandparent, or the spouse, surviving spouse, domestic partner, or surviving domestic partner of any of the foregoing functioned as a parent of the child before the child reached the age of majority $;^{28}$ or (ii) an event, such as death or incapacity, intervened to prevent the genetic parent from functioning in that capacity. ${ }^{29}$ Regarding a class gift created by someone other than the child's genetic parent, the Restatement again adopts a de facto agency concept. Under this concept, the transferor is presumed to view the genetic parent as the transferor's agent. The transferor has in effect ceded authority to the genetic parent to determine who is a member of the transferor's family. If the genetic parent, or one of the listed relatives of the genetic parent, functioned as a parent of the child before the child reached the age of majority, the transferor is presumed to be comfortable with treating the child as a child of the genetic parent for classgift purposes. It is important to keep in mind that this rule of construction deals with donative intent of a nonparent, and is quite different from family law rules that focus on the duty of support properly imposed on parents of nonmarital children. Put another way, the Restatement's rule of construction is based on the idea that the transferor who is not the child's parent has no duty to share his or her property with children who are not voluntarily treated as members of the family, for to attribute to the transferor an intent to do so would deprive genuine family members of that share.

27. See Restatement (ThiRd) of Prop.: Wills and Other Donative Transfers $\$ 14.7$ (Tentative Draft No. 4, 2004).

28. As published in Tentative Draft No. 4, section 14.7 provided that the child was treated as a child of the genetic parent only if the genetic parent functioned as a parent of the child before the child reached the age of majority. As this section will appear in the final published volume, the nonmarital child is treated as a child of the child's genetic parent if the generic parent, the genetic parent's grandparent or a descendant of the genetic parent's grandparent, or the spouse, surviving spouse, domestic partner, or surviving domestic partner of any of the foregoing functioned as a parent of the child before the child reached the age of majority. See supra note 6.

29. See Restatement (ThIRD) OF Prop.: Wills and OTHER DONATIVE TRansfers $\$ 14.7$ (Tentative Draft No. 4, 2004). 


\section{Children of Assisted Reproduction}

The Restatement's position is that a child of assisted reproduction is presumptively treated for class-gift purposes as a child of a person who consented to function as a parent of the child and who functioned in that capacity or intended to function in that capacity but was prevented from doing so by an event such as death or incapacity. ${ }^{30}$ Much of the discussion in the literature has focused on posthumous conception. Although that is an important question, it is only one part of the overall picture. A typical case is that of a married couple who are having difficulty producing a pregnancy. Adoption is always a possibility, but they may first try one or more of the range of solutions offered by fertility clinics, including artificial insemination or in vitro fertilization. If the husband's sperm is used for either procedure, and if the wife's eggs are used for in vitro fertilization, there is no problem - the child is the genetic child of both parents. If the sperm of someone other than the husband is used, or the eggs of someone other than the wife are used for in vitro fertilization, the child is not the genetic child of both parents. If the procedure proves successful, and the wife carries the child to birth, and if the married couple do what is expected and function as parents of the child, the child will be presumptively treated as their child for class-gift purposes. The child is not treated as the child of any third-party sperm or egg donor.

Regarding posthumous conception, the case that comes most readily to mind is that of a member of our armed forces whose unit gets orders to deploy to a war zone, such as Iraq or Afghanistan. He is recently married, perhaps has a young baby or his wife is pregnant with their first child. Before departing for the war zone, he leaves sperm in a sperm bank for use by his widow in case he does not make it back alive. Tragically, he is killed in action. After a reasonable period of grieving, his widow decides to use the frozen sperm to get pregnant and bear his child. Suppose that the soldier's mother had died several years earlier, creating a trust that paid the income to him for life, remainder in principal to his "children" (or "issue"). Is the posthumous child to be treated as a member of the class or not? Under the Restatement's position, the child would presumptively be treated as a member of the class, assuming that the child was born within a reasonable time after the soldier's death. ${ }^{31}$

30. See id. $\S 14.8$.

31. See id. $\S 15.1, \mathrm{cmt}$. $\mathrm{j}$ (providing that in cases in which the distribution date is the deceased parent's death, a child conceived posthumously by assisted reproduction is treated as in being at the decedent's death for purposes of the class-closing rules if the child was born within a reasonable time after the decedent's death). Determining whether birth occurred within a reasonable time after the decedent's death requires a balancing of the interests in final settlement of trusts and estates and allowing the surviving 
There have been a few litigated cases dealing with the status of children conceived posthumously by assisted reproduction. ${ }^{32}$ None of the litigated cases so far have involved the case of a soldier killed in action. They have all involved a husband who is diagnosed with cancer. Before undergoing chemotherapy, which could render him infertile, he deposits sperm in a sperm bank for use by his wife or, should he succumb to the illness, by his widow. He does succumb to the illness, and after his death, his widow becomes pregnant with his child. Just as in the case of the soldier's child, the Restatement's rule would presumptively treat the child as a child of the deceased husband for class-gift purposes, assuming that the child was born within a reasonable time after the husband's death (as the children were in these three cases).

One of the most difficult questions in the case of posthumous conception is determining the decedent's intention. The Restatement's position, as noted above, is that the child is a child of a person who consented to function as a parent of the child and who functioned in that capacity or intended to function in that capacity but was prevented from doing so by an event such as death or incapacity. Intent to function as a parent of the resulting child must be shown by any relevant evidence. In contrast, the Uniform Parentage Act requires consent in a record to posthumous conception. ${ }^{33}$ The State of California has come up with a solution that will solve many and probably most cases. A California statute requires all genetic depositories to provide a form that, if signed by the depositor, would state the depositor's intent. ${ }^{34}$ Unfortunately, the imposition of such a requirement is beyond the scope of a Restatement, so this solution must be left to legislation. ${ }^{35}$

spouse or domestic partner time to grieve before making a decision whether to go forward with an assistedreproduction procedure, and how soon after death an attempt was made to produce a pregnancy through assisted reproduction, whether successful or not. In cases in which the distribution date arises after the deceased parent's death, a child conceived posthumously by assisted reproduction is in being on the date of conception for purposes of the class-closing rules, just as is any other child.

32. See Gillett-Netting v. Barnhart, 371 F.3d 593 (9th Cir. 2004), rev'g 231 F.Supp.2d 961 (D. Ariz. 2002); In re Kolacy, 753 A.2d 1257 (N.J. Super. Ct. Ch. Div. 2000); Woodward v. Comm'r of Soc. Security, 760 N.E.2d 257 (Mass. 2002). These cases involved Social Security survivor benefits for the children as dependents of the deceased father, not whether the child was presumptively a member of a class created in a donative document.

33. See UNIF. PARENTAGE ACT $\$ 707$ (2000).

34. See CAL. HEALTH \& SAFETY CODE $\$ 1644.7-8$.

35. Imposition of such a requirement is also beyond the scope of a probate code, including the Uniform Probate Code. The current draft of the Uniform Probate Code amendments, however, contains a "Legislative Note" recommending enactment of such a requirement in the part of the state's statutory structure that regulates genetic depositories. See supra text accompanying note 7, Drafts of the Uniform Probate Code amendments can be downloaded from the Uniform Law Commissioners' website, http://nccusl.org (last visted July 1, 2007). 


\section{Stepchildren and Other Relatives by Marriage}

The Restatement's rule of construction on this question is the traditional one: Unless the language or circumstances establish that the transferor had a different intention, a term of family relationship in a class gift does not include stepchildren or other relatives by marriage. ${ }^{36}$ The Restatement gives a couple of situations in which the circumstances would tend to rebut the presumption, resulting in inclusion of a relative by marriage. One is the situation in which, looking at the facts existing when the donative document was executed, the class was then and foreseeably would be empty unless the transferor intended to include relatives by marriage. Another is the case of reciprocal wills. Suppose that the husband's will devises his entire estate "to my wife if she survives me, but if not, to my nieces and nephews," and the wife's will devises her entire estate "to my husband if he survives me, but if not, to my nieces and nephews." Both husband and wife have nieces and nephews. The husband dies first. All of his property passes to his widow. On her subsequent death, the term "my nieces and nephews" is presumptively construed to include her nieces and nephews by marriage (her husband's nieces and nephews). Were it otherwise, the combined estates of husband and wife would pass only to the nieces and nephews of the spouse who happened to survive.

\section{INCREASE AND DECREASE IN CLASS MEMBERSHIP}

Chapter 15, Increase and Decrease in Class Membership, addresses one of the distinguishing features typical of a class gift-that the potential takers can fluctuate in number until the class closes and the property is entitled to be distributed to the then-eligible class members. Increase in a class occurs when a new member is added to the class on account of birth, adoption, marriage, or for some other reason. Decrease in a class occurs because a class member fails to satisfy a requirement of survival or some other requirement.

\section{A. Increase in Class Membership}

As noted, increase in a class occurs when a new member is added to the class on account of birth, adoption, marriage, or for some other reason. A class gift that is subject to increase is said to be "subject to open" or, under older terminology, "subject to partial divestment." When a new member is added to a class, the shares of existing class members abate proportionally. ${ }^{37}$

36. See Restatement (ThiRd) OF Prop.: WiLls and Other Donative Transfers $§ 14.9$ (Tentative Draft No. 4, 2004).

37. See id. $\$ 13.1 \mathrm{cmt}$. h. 
The ability of a class to increase must come to an end at some point. Of course, the ability of a class to increase is ended when it is no longer physiologically capable of increasing. A class closes physiologically when events that can cause a class to increase become physiologically impossible, events such as births or adoptions. The physiological closing of a class is traditionally based on the assumption that death terminates the possibility of having children. Thus, a class gift in the transferor's will to the transferor's children physiologically closes upon the transferor's death, and a class gift to the transferor's grandchildren physiologically closes upon the death of the transferor's last living child-tempered only by the rule that a child then in gestation is treated as then living if the child is subsequently born viable. ${ }^{38}$

Under the so-called class-closing rules, however, a class can be closed to future entrants before it closes physiologically. The class-closing rules are governed by an ancient rule of construction known as the rule of convenience. Whether the class gift is to an immediate or a postponed class, the rule of convenience is based on a single principle: a class that has not yet closed physiologically closes when a beneficiary is entitled to distribution of his or her share. ${ }^{39}$ Because the beneficiaries of a class gift take on a fractional basis ${ }^{40}$ the time of distribution even for one beneficiary of the class gift requires the determination of that beneficiary's share. The numerator of the fraction for each then-entitled beneficiary is one, but the denominator cannot be known unless the maximum membership of the class is finalized at that point. The need to finalize the maximum membership of the class requires that the class close then.

In the case of an immediate class gift in a will, the class closes at the testator's death because that time is treated as the distribution date. In the case of a postponed class gift in the principal of a trust distributable at the death of the income beneficiary, the class closes at the income beneficiary's death because that time is treated as the distribution date. Although the actual distribution of the property never takes place when the testator or the income beneficiary dies, and is necessarily delayed for administrative reasons, the rule of convenience treats the time of death in both cases as the time when the class closes. By treating the time of death as the time when the class closes, the rule of convenience contributes certainty and eliminates the possibility of manipulation that would arise if the time of closing were delayed until the time of actual distribution.

Once a class has been closed by the rule of convenience, persons not yet in being are not entitled to participate in the class gift, even though they

38. See id. $\S 15.1 \mathrm{cmts}$. h-i.

39. See id. § 15.1 .

40. See id. $\S 13.1 \mathrm{cmt}$. i. 
otherwise fit the class label. New entrants come into a class only if they are come into being while the class is still open. A class member who is in gestation or in the process of being adopted when the class closes is regarded as in being on the closing date. ${ }^{41}$

Now, however, frozen sperm, ova, and embryos make it possible to have children by assisted reproduction after death. ${ }^{42}$ The position of the Restatement on this question is that in cases in which the distribution date is the deceased parent's death, a child conceived posthumously by assisted reproduction is treated as in being at the decedent's death for purposes of the class-closing rules, if the child was born within a reasonable time after the decedent's death. ${ }^{43}$ Determining whether birth occurred within a reasonable time after the decedent's death requires a balancing of the interest in final settlement of trusts and estates and allowing the surviving spouse or domestic partner time to grieve before making a decision whether to go forward with an assisted-reproduction procedure, and how soon after death an attempt was made to produce a pregnancy through assisted reproduction, whether successful or not. In cases in which the distribution date arises after the deceased parent's death, a child conceived posthumously by assisted reproduction is in being on the date when the child is in utero for purposes of the class-closing rules, just as is any other child.

\section{B. Decrease in Class Membership}

Decrease in a class occurs because a class member fails to satisfy a requirement of survival or some other requirement. A will takes effect as a dispositive instrument at the testator's death, not when the will was executed. ${ }^{44}$ Hence, all devisees in a will, including the beneficiaries of a class gift, must survive the testator. ${ }^{45}$ A class member who fails to survive the testator is excluded from the class, ${ }^{46}$ subject to the possible substitution of his or her descendants by application of the antilapse statute of the controlling jurisdiction. $^{47}$

41. See Restatement (Third) OF Prop.: Wills and Other Donative Transfers $\S 15.1 \mathrm{cmts}$. h-i (Tentative Draft No. 4,2004$)$.

42. See id. $\$ 14.8 \mathrm{cmt} . \mathrm{h}$.

43. See id. $\$ 15.1 \mathrm{cmt}$. j.

44. See Restatement (ThIRD) OF PROP.: WILls AND OTHER DONATIVE TRANSFERS $\$ 3.1 \mathrm{cmt}$. a (1999).

45. See id. $\S 1.2 \mathrm{cmt}$. e; $\S 5.5 \mathrm{cmt}$. a.

46. See Restatement (ThIRD) OF PROP.: Wills and OTHER DONATIVE TRANSFERs $\S 15.2$ (Tentative Draft No. 4, 2004).

47. Antilapse statutes apply to class gifts to single-generation classes, whether or not the language of the statute explicitly covers class gifts. Antilapse statutes do not, however, apply to class gifts to multiple-generation classes, such as gifts to "issue," "descendants," "heirs of the body," "heirs," "next of 
In the case of a postponed class gift, typically a remainder interest taking effect on the death of the income beneficiary of a trust, the problem of decrease in class membership raises a question of whether the remainder interest is subject to a requirement of survival of the income beneficiary. If the class gift is a multiple-generation class gift (such as a remainder interest to the income beneficiary's "issue" or "descendants"), the rule of construction generally followed in the case law ${ }^{48}$ and adopted by the Restatement is that there is an implied condition of survival of the income beneficiary. ${ }^{49}$ Here is a slightly modified version of an illustration used in the Restatement:

Grantor created a revocable inter-vivos trust, directing the trustee to pay the income to Grantor for life, then to pay the income to Grantor's daughter LT for life, then to pay the principal of the trust "to LT's issue." LT, who survived Grantor, had three children, C1, C2, and C3. C1 survived Grantor and LT. C2 survived Grantor but predeceased LT, leaving issue who survived LT. C3 survived Grantor but predeceased LT. C3 had one child, GC, who also predeceased LT. GC had no issue. Half of the principal of the trust passes to C1. The other half passes to C2's issue who survived LT, to be divided among them by representation. C3's line is excluded because it has no living member on the distribution date. ${ }^{50}$

The rationale for implying a condition of survival in the case of a multiplegeneration class gift is that a future interest to issue or descendants is presumptively divided by representation ${ }^{51}$ in a process of substitution that continues throughout the life of the income beneficiary. A descendant who dies before the distribution date with issue is replaced in the class by his or her issue who survive the distribution date. A descendant who dies before the distribution date without issue is not replaced, because that descending line has died out. The share of a descendant who dies without issue before the

kin," "relatives," or "family," because these types of class gifts already pass the shares of deceased class members to their surviving descendants without statutory intervention.

Under a typical antilapse statue, in the absence of a contrary intent, the property bequeathed or devised to a single-generation class is divided among the class members who survive the testator, if any, and the descendants of deceased class members who survive the testator, if any. Each surviving class member takes the share that he or she would have taken had the deceased class members also survived the testator. Each deceased class member's surviving descendants take by representation the share that the deceased class member would have taken had the deceased class member survived the testator. A class member who fails to survive the testator and leaves no descendants who survive the testator is disregarded.

48. See, e.g., cases and other authorities cited in RESTATEMENT (THIRD) OF PROP.: WILLS AND OTHER DONATIVE TRANSFERS $§ 15.3$ Reporter's Note No. 1 (Tentative Draft No. 4, 2004).

49. See id. § 15.3 .

50. See id. $\S 15.3$ illus. 1.

51. See id. $\S 14.3$. 
distribution date is shifted to the other descending lines that still have living issue on the distribution date. To give maximum effect to this process, it continues until the distribution date (LT's death in the above example). This process is the primary basis for implying a condition of surviving the distribution date..$^{52}$

The importance of careful drafting cannot be overemphasized here, because the careful drafting attorney will not leave this question to be resolved by a rule of construction, when it is so easy to clarify the disposition by drafting the remainder interest to state: "to LT's issue who survive LT, to be divided among them by [specify the system of representation to be used]." 53

A completely different problem is posed if the postponed class gift is a single-generation class gift (such as a remainder interest to the income beneficiary's "children"). The rule of construction generally followed in the case law $^{54}$ and now perpetuated in the Restatement is that there is no implied condition of survival of the income beneficiary. ${ }^{55}$ Consider the above example, but change the remainder interest to read "to LT"s children" instead of "to LT's issue." Under the common-law rule of construction, one-third of the principal would pass to $\mathrm{C} 1$, one-third would pass through the estate of $\mathrm{C} 2$, and one-third would pass through the estate of $\mathrm{C} 3{ }^{56}$ The consensus among the Reporters, Advisers, Consultative Group Members, and the Council of the Institute is that the likely preference of most transferors would not be in favor of the result produced by the common-law rule of construction. The consensus view was that most transferors would prefer that half pass directly to $\mathrm{C} 1$ and half to $\mathrm{C} 2$ 's descendants, just as in the example above of the multiple-generation class gift.

At the suggestion of the Council, the Reporter and Associate Reporter presented the Institute with a choice between two options. One option was the adoption of the common-law rule of construction (the traditional option) and the other option was the following antilapse-type option:

52. This rule of construction is also supported by the strong constructional preferenceset forth in the Restatement, RESTATEMENT (THIRD) OF PROP.: WILLS AND OTHER DONATIVE TRANSFERS $§ 11.3(\mathrm{c})(3)$ (2003), favoring the construction that does not disinherit a line of descent having one or more living members on the distribution date and excluding a line of descent that then has no living member.

53. RESTATEMENT (THIRD) OF PROP.: WILLS AND OTHER DONATIVE TRANSFERS $\$ 2.3 \mathrm{cmts} . \mathrm{c}-\mathrm{g}$ (1999) (discussing the different systems of representation and the different meanings attributed to the term "per stirpes"). The Uniform Probate Code section 2-709 contains a useful definition of "per stirpes" that can be adapted to private documents, as well as the definition of the per-capita-at-each-generation system of representation that is adopted in the Uniform Probate Code section 2-106 for intestacy. See Raymond H. Young, Meaning of "Issue" and "Descendants," 13 ACPC PROBATE NOTES 225 (1988).

54. See, e.g., Restatement (ThIRD) OF PROP.: WILL AND OTHER DONATIVE TRANSFERS 15.4 Reporter's Note No. 1 (Tentative Draft No. 4, 2004).

55. See id. $\S 15.4$.

56. See id. 
Unless the language or circumstances establish that the transferor had a different intention, a beneficiary of a postponed single-generation class gift who fails to survive the distribution date is excluded from the class. The share that the deceased class member would have taken had he or she survived the distribution date passes by representation to the class member's descendants who survive the distribution date. If the deceased class member leaves no descendants who survive the distribution date, that share passes to the class members who survive the distribution date and by representation to the descendants who survive the distribution date of any other class member who predeceases the distribution date.

Both options were debated at length in the deliberations of the Institute. The Reporters were in the odd position of favoring the antilapse-type option on the merits, but opposing it as a Restatement rule, considering that Restatements are developed for adoption by courts, not enactment by legislatures. The Institute voted to adopt the traditional option, but only by a margin of seven votes. ${ }^{57}$ The Reporters favored the traditional option because they were concerned that courts would be unwilling to adopt the antilapse-type option. Doing so would require the court to insert a substitute gift based on likely preferences lacking any foundation in the language of the instrument of transfer. The traditional technique of the common law is construction, not insertion of a gift that does not appear in the language of the document or that cannot be implied from the language of the document.

If one dispenses with the ancient dogma that the law favors the vesting of estates, the strongest modern justification for the traditional option is "that it enables the deceased class member to pass his share to his issue, thereby keeping the benefits of the gift equal among the descendant lines." ${ }^{.8}$ This is sometimes known as the "trickle-down" theory. Under this theory, the share of a deceased class member will descend through the class member's estate and, when the trust is dissolved at some later time, might end up benefiting the deceased class member's descendants. The traditional option produces the best chance within the common-law tradition of protecting a descending line that has one or more living members on the distribution date.

It would probably be within the traditional technique of the common law to construe single-generation class gifts as presumptively being subject to an implied condition of survival of the distribution date. By itself, however, an implied condition of survival would make it impossible for the trickle-down

57. See A.L.I. PROC. 192 (2004). a (1988).

58. See Restatement (SECOND) Of PROP.: WILLS AND OTHER DONATIVE TRANSFERS $\S 27.3 \mathrm{cmt}$. 
theory to work. Unless a court is willing to couple a survival requirement with a blanket presumption creating a substitute gift to the descendants of a deceased class member, merely implying a condition of survival in all cases would extinguish the possibility of benefit to the deceased class member's descendants.

The principal weakness of the traditional option is this: Although the share of a deceased class member might end up in the hands of the deceased class member's descendants, it might not. The deceased class member might die without issue. The deceased class member might die intestate, in which case there might be multiple heirs, one or more of whom also predecease the distribution date. On the distribution date, the deceased class member's share can easily pass to complete strangers. To be sure, a class member who survives the distribution date can also pass his or her share to complete strangers, but at least the class member who survives the distribution date has the right to enjoy his or her share personally.

Consequently, the traditional option is a crude and costly means of protecting the deceased class member's descendants from disinheritance, but probably is the only means of doing so within the traditional technique of the common law. Nevertheless, although the Institute's final vote adopted the traditional option, the Restatement Comment urges any court that is willing to do so to adopt the antilapse-type option. ${ }^{59}$ The Restatement Comment also points to a line of authority in which courts have construed a class gift to children to mean a class gift to issue ${ }^{60}$ which is a means of producing an antilapse-type result by construction.

The above discussion of single-generation class gifts carries a major drafting lesson. Single-generation class gifts should be avoided for clients who do not want to disinherit a descending line that has living members on the distribution date but does want to disinherit a descending line that has died out by the distribution date. For such clients, a multiple-generation class gift to "issue" or "descendants" is to be preferred.

\section{CLASS GifTS TO HEIRS}

Chapter 16, Class Gifts to Heirs, deals with a type of class gift that is deceptively difficult to draft without ambiguity-a class gift to "heirs" (or the like, such as to "next of kin"). Consider the will of John F. Dodge, the co-

59. See Restatement (THIRD) OF PROP.: WILLS AND OTHER DONATIVE TRANSFERS $\$ 15.4 \mathrm{cmt}$ i (Tentative Draft No. 4, 2004).

60. See id. $\S 15.4 \mathrm{cmt}$. h (citing id. $\S 14.1 \mathrm{cmt} . \mathrm{g}$ ). 
founder of the company that produced the Dodge automobile. ${ }^{61}$ Dodge's will created a testamentary trust that provided:

[U]pon the death of all of my said children, Winifred Dodge Gray, Isabella Cleves Dodge, Frances Matilda Dodge and Daniel George Dodge [who were the income beneficiaries of the trust], then I direct my said trustees to convey my said estate to the heirs of my said children, Winifred Dodge Gray, Isabella Cleves Dodge, Frances Matilda Dodge and Daniel George Dodge, in such proportion as by law such heirs shall be entitled to receive same.

In In re Dodge Testamentary Trust, ${ }^{62}$ the court identified several ambiguities in this clause. One of the obvious ambiguities is that the class gift was to the heirs of four named persons. The court properly resolved this ambiguity by interpreting it to mean that one-fourth of the trust principal was to go to the heirs of each of the four, rather than one class composed of the collective heirs of all four. One has to wonder what the drafting attorney was thinking in crafting a class gift to the heirs of four named persons, or whether the drafting attorney was thinking at all. In any event, once the provision was interpreted to mean that one-fourth of the principal was to go to the heirs of Winifred, one-fourth to the heirs of Isabella, one-fourth to the heirs of Frances, and one-fourth to the heirs of Daniel, the court proceeded to identify and resolve other ambiguities.

In effect, a class gift to heirs incorporates by reference the intestacy statute to determine who the takers are, but which intestacy statute? Is it the statute of the testator's domicile or of the designated ancestor's domicile? Is it the statute in effect when the testator dies, when the designated ancestor dies, or on the distribution date? In the Dodge case, John Dodge and three of his four named children (Winifred, Frances, and Daniel) died domiciled in Michigan. Isabella died a resident of Florida. Winifred died in 1980, Frances in 1971, Isabella in 1962, and Daniel in 1938. Because Winifred (the oldest) was the last to die of the four, her death marked the distribution date.

The Restatement adopts a rule of construction that presumptively resolves the ambiguities in a class gift to heirs by providing that unless the language or circumstances establish that the transferor had a different

61. John F. Dodge died in New York while on a trip with Horace Dodge, his brother and co-founder of the Dodge Brothers machine shop, which later produced the Dodge automobile. The Dodge brothers were on a trip to the National Automobile Show where Dodge cars were on display. John was an early victim of an influenza epidemic that swept New York. Horace also contracted influenza, as did John's wife Matilda, who upon learning of John's illness took the first train to New York to be at his bedside. Matilda was so sick that she was unable to attend her husband's funeral back in Detroit. Horace died in Palm Beach later that year of a relapse. See JEAN MADDERN PITRONE, Tangled Web: Legacy of Auto Pioneer John F. Dodge 94-98 (1989).

62. 330 N.W.2d 72 (Mich. Ct. App. 1982). 
intention, a class gift to the "heirs" of a designated person means the persons who would succeed to the designated person's intestate estate if the designated person died intestate on the distribution date owning only the subject matter of the gift. ${ }^{63}$ As applied to the Dodge case, and assuming that the rule of construction would not have been rebutted by contrary language or circumstances (which it would not have been, because there was no evidence bearing on John Dodge's actual intention), the trust principal would have been distributed as follows: one-fourth to the heirs of Winifred under the Michigan statute of intestacy in effect at her death; one-fourth to the persons who would have been the heirs of Frances if she had died when Winifred died, i.e., under the Michigan statute of intestacy in effect at Winifred's death; one-fourth to the persons who would have been the heirs of Daniel if he had died when Winifred died, i.e., under the Michigan statute of intestacy in effect at Winifred's death; and one-fourth to the persons who would have been the heirs of Isabella if she had died when Winifred died, i.e., under the Florida statute of intestacy in effect at Winifred's death. ${ }^{64}$ The benefit of this rule of construction is that if the designated person died before the distribution date (as three of the four Dodge children did), the property is distributed directly to the person's closest family members who are living on the distribution date. This construction avoids reopening the estates of any heirs who were living at the designated person's death, but who died before the distribution date. It also spares having to identify and trace their successors in interest, who might or might not be family members.

The Restatement's rule of construction is supported by modern statutory law ${ }^{65}$ and can be adapted for use in private documents by attorneys drafting a class gift to heirs.

The chapter on class gifts to heirs closes with two sections providing that two ancient rules are no longer recognized ${ }^{66}$ - the Rule in Shelley's Case (which stated that a remainder interest to the heirs of a life tenant went to the

63. See Restatement (ThiRd) of Prop.: Wuls and Other Donative Transfers § 16.1 (Tentative Draft No. 4, 2004).

64. The court in the Dodge case reached different results. The court held that the Michigan statute in effect at the death of each child should control. See Dodge, 330 N.W.2d 72.

65. Alaska StaT. § 13.12 .711 (2007); ARIZ. Rev. Stat. ANN. \& 14-2711 (2007); Cal. Prob. CODE $\$ 21114$ (West 2007) (differing from the Restatement by providing that the intestacy statute of the transferor's domicile applies); CoLo. REv. STAT. § 15-11-211 (2007); HaW. REV. STAT. \& 560:2-711 (2007); Mich. COMP. LAWS ANN. $\$ 700.2720$ (West 2007); MNN. STAT. ANN. $\$ 524.2-711$ (West 2007); MONT. CODE ANN. § 72-2-721 (2007); N.M. STAT. ANN. § 45-2-711 (West 2007); N.D. CENT. CODE § 30.1-09.1-11 (2007); 20 PA. CONS. STAT. § 2514 (2007); S.D. CODIFIED LAWS § 29A-2-711 (2007); UTAH CODE ANN. § 75-2-711 (West 2007); WASH. Rev. CODE § 11.12 .180 (2007); WIS. STAT. §§ 700.11, 854.22(1) (2007). Most of these statutes are based on section 2-711 of the Uniform Probate Code.

66. In the language of Tentative Draft No. 4, these rules are "repudiated." RESTATEMENT (THIRD) OF PROP.: WILLS AND OtheR DONATIVE TRANSFERS $\$ \$ 16.2,16.3$ (Tentative Draft No. 4, 2004). The final published version will say that these rules are "not recognized as part of American law." 
life tenant, not to the life tenant's heirs) and the Doctrine of Worthier Title (which stated that a remainder interest to the heirs of the transferor presumptively created a reversion in the transferor, not a remainder in the transferor's heirs).

\section{CONCLUSION}

The new Restatement (Third) of Property is an important resource for both lawyers and judges. The first two published volumes are beginning to influence the development of American law on a variety of fronts. ${ }^{67}$ The soonto-be-published third volume, covering class gifts and powers of appointment, could prove to be equally influential.

The material on class gifts addresses not only traditional topics, such as what is a class gift and questions of increase and decrease in class membership, but the cutting edge issues concerning the status for class gift purposes of children of assisted reproduction, as well as adopted children and nonmarital children. The new Restatement promulgates nuanced rules of construction on all of these matters. As such, they are ripe for adoption not only in case law, which constitutes a Restatement's natural sphere of influence, but also in the definitions section of private donative documents ${ }^{68}$ and in legislation. ${ }^{69}$

67. See supra notes 1-3.

68. See supra Part III.

69. See supra text accompanying note 7 . 